\title{
Successful Weight Loss Surgery Improves Eating Control and Energy Metabolism: A Review of the Evidence
}

\author{
Dave H. Schweitzer, MD, PhD1; Emile F. Dubois, MD, PhD²; Niki van den \\ Doel-Tanis, BS ${ }^{1}$; Hok I. Oei, MD ${ }^{3}$
}

Departments of ${ }^{1}$ Internal Medicine and Endocrinology, ${ }^{2}$ Pulmonary Diseases, and ${ }^{3}$ Surgery, Reinier de Graaf Groep, Delft-Voorburg, The Netherlands

\begin{abstract}
Eating behavior is determined by a balance of memories in terms of reward and punishment to satisfy the urge to consume food. Refilling empty energy stores and hedonistic motivation are rewarding aspects of eating. Overfeeding, associated adverse GI effects, and obesity implicate punishment. In the current review, evidence is given for the hypothesis that bariatric surgery affects control over eating behavior. Moreover, any caloric overload will reduce the feeling of satiety. Durable weight loss after bariatric surgery is probably the result of a new equilibrium between reward and punishment, together with a better signaling of satiation due to beneficial metabolic changes. We propose to introduce three main treatment goals for bariatric surgery: 1) acceptable weight loss, 2) improvement of eating control, and 3) metabolic benefit. To achieve this goal, loss of $50 \%$ to $70 \%$ of excess weight will be appropriate (i.e. $30 \%$ to $40 \%$ loss of initial weight), depending on the degree of obesity prior to operation.
\end{abstract}

Key words: Bariatric surgery, control, eating behavior, hunger, regulation, satiety, safe surgery

\section{Introduction}

The public health situation of many industrialized countries is jeopardized by the increasing incidence

Correspondence to: Dave H. Schweitzer, MD, PhD, Dept. of Internal Medicine and Endocrinology, Diaconessenhuis, Reinier de Graaf Groep Hospital, Fonteynenburghlaan 5, 2275 CX Voorburg, The Netherlands. Fax: +31 70 3594902;

e-mail: schweitzDH@rdgg.nl or myradave@xs4all.nl of obesity and related cardiovascular disease., ${ }^{1,2}$ The alarming situation is clearly related to our modern way of living, implicating ad libitum access to food and sedentary lifestyle. The prevalence of obesity increases every year and overrules our tightly controlled energy homeostasis, which tries to keep body weight within narrow boundaries. ${ }^{3,4}$ Nationwide campaigns against obesity and associated cardiovascular disease are mainly focused on signs and symptoms of the metabolic syndrome. For example, the diagnostic criteria proposed by the American National Cholesterol Education Program-Adult Treatment Panel III (NCEP-ATPIII) are understandable and can be managed with caloric restriction, exercise, and modern effective drugs. ${ }^{5}$ However, many motivated obese patients try hard to reduce weight but gradually lose control of eating behavior, become disappointed, and finally undergo bariatric surgery. Notably, each surgical technique has its specific advantages and drawbacks. For example, laparoscopic adjustable gastric banding (LAGB) is a restrictive technique, which is appropriate for patients with a body mass index (BMI) $<50 \mathrm{~kg} / \mathrm{m}^{2}$ and without extreme eating disorders. In this respect, a long-term follow-up study among individuals who underwent LAGB showed 'treatment failure' in about $37 \%$ after 7 years. ${ }^{6}$ On the other hand, gastric bypass (GBP) and biliopancreatic diversion (BPD) combined with restrictive techniques are clearly more effective to maintain durable weight loss. ${ }^{7}$ Because there are no safety follow-up data $>10$ 
years, GBP with just a minimal degree of malabsorption has earned the reputation as the 'gold standard' against all other procedures.

The current review explains the critical role of bariatric surgery to improve eating behavior and reset metabolism. In the first place, weight loss surgery emphasizes punishment after too much or too fast food consumption. Secondly, since intake of inappropriately high amounts of calories suppresses satiety, too much food is regarded as a metabolic disadvantage. We propose to perform weight loss surgery for what most people accept as cosmetically acceptable weight reduction, improvement of eating control, and a beneficial change of the balance between hunger and satiety. In other words, behavioral and medical arguments are brought together to reason weight loss surgery.

\section{Eating Behavior}

\section{Associative Learned Networks that Compose Eating Behavior}

The conditioned reflex of eating behavior was fundamentally pioneered by Pavlov. ${ }^{8}$ In his classic "sham" feeding studies performed on dogs with an esophageal stoma and a gastric fistula, Pavlov demonstrated that food was a prompt and powerful stimulant of gastric secretion. This so-called 'cephalic phase' of gastric acid secretion occurred despite the fact that the ingested food entered the dog's mouth and pharynx without reaching the stomach. Pavlov went on to demonstrate that dissecting the vagus nerve just above the diaphragm abolished this response to sham feeding. Sham feeding in humans by chewing and expectorating food without swallowing revealed similar reproducible results and even thinking about food is a strong stimulant of gastric acid production. ${ }^{9,10}$ Sham feeding is a typical example of a conditioned stimulus that goes along with a paired digestive response (cue). Beyond simple cues related to motor and secretory responses, there are far more complex interacting cues that all together form a memorized network of learned stimulus-response interactions. ${ }^{11}$ Eating behavior is primarily conditioned by the simple 'hunger' cue and on top of it by a complex network of memories related to eating. Fundamentally, this network is critical to condition individuals to fill their empty energy stores. ${ }^{12}$

\section{Eating for Pleasure (Hedonism)}

Eating behavior is also, at least in part, attributable to the assault by daily food-related stimuli while there are no physical energy requirements. ${ }^{13,14}$ For example, today's continuous bombardment of food-related cues by advertisements about food and catchy jiggles from fast-food restaurants tightens our eating behavior networks, stimulates overfeeding and overrides the natural cues of satiety. ${ }^{15}$ Obviously, our original goals to eat in order to fill energy stores become replaced by eating behavior that satisfies hedonistic desires. ${ }^{16}$ The fulfilment of biological requirements as well as hedonistic drives leads to satisfaction using our reward circuitry, which in part resides in dopaminergic circuits in the nucleus accumbens. ${ }^{17-19}$ The stronger the reward value of a specific food-related cue, which is in part conveyed by its prediction from previously memorized experiences, the stronger the demand to get more of it, i.e. 'wanting'. Palatable food has a high reward value, i.e. 'liking', and a lot of its ingestion may even lead to addictive behavior, craving and subsequent obesity. ${ }^{20}$ Research points to the direction that 'wanting' is mediated by dopaminergic neurotransmission, whereas 'liking' is mediated by opioid pathways. ${ }^{21}$ In humans, it has been shown that palatable food is capable of enhancing 'wanting', while it hardly affects 'liking'. ${ }^{22}$ This situation resembles that of chronic substance abuse, meaning craving without liking.

\section{Hunger Regulation}

\section{Feedback between Body Fat and Brain}

Besides the behavioral aspects of eating, hunger and satiety are mainly centrally regulated by energy homeostasis. This mechanism is designed to keep our body weight tightly regulated. In order to gain weight, adaptations of energy homeostasis are essential to alter its set-point. Moreover, weight gain and obesity are associated with insulin resistance, which raises the fundamental question whether adaptations of energy homeostasis are linked to insulin resistance. By definition, energy homeostasis is the biological process in which energy intake is matched to energy expenditure over time, to promote stability of body fuel that is stored in the form of fat. The idea of an 'adiposity negative feedback control system' was for the first time 
suggested in the early 1970s. ${ }^{23}$ Storage of body fat, being the regulated variable, stands at the bottom of this system, whereas food intake is the major determinant of how much body fat will be stored.

It was furthermore hypothesized that efferent circulating signals, produced in proportion to fat mass, would act in the brain to slow down food intake. In this concept, starvation or drastic lowering of food intake diminishes body fat, including its negative feedback signals, thereby activating the brain to stimulate hunger. ${ }^{23}$ Today, there is solid evidence that hypothalamic centers control the regulation of feeding behavior and energy homeostasis. ${ }^{24}$

Moreover, insulin is a potential mediator of adiposity-related negative feedback signaling. ${ }^{25-27}$ The hormone circulates in proportion to fat mass, crosses the blood-brain barrier, and acts on key brain pathways that are connected to the liver by efferent neuronal input. In the brain, insulin directs the vagus nerve to inhibit glycogenolysis in the liver in a situation of energy store repletion. ${ }^{27,28}$ Insulin infusion directly into the brain decreases appetite and food intake, leading to weight loss. On the contrary, artificial disruption of receptor signaling for insulin in key brain areas increases hepatic glucose production, appetite, food intake and leads to weight gain. ${ }^{29,30}$ Furthermore, laboratory animals lacking the insulin receptor substrate-2 (IRS-2) have increased food intake and obesity. ${ }^{31}$ These findings were the first evidence to suggest a role for 'brain insulin signaling' in the control of food intake and energy homeostasis.

Parallel to insulin resistance, leptin is increasingly secreted by adipocytes and acts as the second powerful mediator of adiposity-related negative feedback signaling. Like insulin, leptin directly infused into the brain decreases appetite, food intake and body weight, whereas a defect of leptin signaling in key brain areas increases appetite, food intake and body weight. ${ }^{32,33}$ Moreover, evidence suggests that central leptin action, as well as insulin, regulates energy homeostasis via neuronal pathways that are partly overlapping, as previously reviewed. ${ }^{34}$

\section{Common Signal Transduction in the Regulation of Hunger and Satiety}

Brain-specific insulin receptors, involved in energy homeostasis regulation, are mainly located in the area of the medio-basal hypothalamus, the portion that includes the arcuate nucleus (ARC) ${ }^{35}$ Insulin binds to its receptor and generates signal transduction by the intracellular signaling pathway known as insulin receptor substrate phosphatidylinositol 3-kinase (IRS/ PI 3-kinase). ${ }^{36}$ Basically, insulin binds to the extracellular domain of its receptor and activates tyrosine kinase activity, thereby creating a binding site for different isoforms of the IRS protein family. ${ }^{37,38}$ The IRS isoforms that become phosphorylated act as docking proteins for several proteins including PI 3-kinase. ${ }^{39}$ Notably, a part of leptin signal transduction in hypothalamic key areas is also using IRS/ PI 3-kinase..$^{40,41}$

The leptin receptor is a cytokine receptor that leads to the activation of a signaling cascade involving Janus kinase and signal transducer and activator of transcription 3 (Jak-STAT3). ${ }^{42,43}$ Interestingly, (Jak-STAT3) signaling shares connectivity with IRS/ PI 3-kinase signaling, as Jak also uses the IRS protein family as substrate. ${ }^{36,41,44}$ For this reason it is believed that IRS/ PI 3-kinase signal transduction in $\mathrm{ARC}$ acts as relay for both hormones, insulin and leptin, in the regulation of energy homeostasis. ${ }^{40,41}$ Insulin and leptin signal transduction in ARC tunes the equilibrium between feeding behavior inhibiting peptides, i.e. proopiomelanocortin (POMC) and cocaine and amphetamine-regulated transcript (CART) and feeding behavior promoting peptides, i.e. neuropeptide Y (NPY) and agouti-related protein (AGRP), as previously reviewed. ${ }^{45-49}$

\section{Diminished Satiety Feelings due to Nutrient Excess}

The notion that similar hypothalamic signal transduction systems are involved in the regulation of energy homeostasis and insulin sensitivity raises the question how nutrient excess is involved in this regulation. Obese individuals who have recently lost substantial amounts of weight became insulinresistant when put on a short-term hypercaloric diet, while lean individuals remained sensitive to insulin under identical circumstances. ${ }^{50}$ This phenomenon is explained, at least to some extent, by the ability of nutrient excess to block the activation of IRS/ PI 3kinase signal transduction. ${ }^{51}$ Indeed, blunting of signal transduction by macronutrients has been observed in peripheral tissues as well as in brain tissue. ${ }^{29,52,53}$ Lastly, cumulating data have indicated that free fatty acids (FFAs) and glucose are each 
capable of increasing hepatic sensitivity to insulin and of reducing hepatic glucose production. These macronutrients were directly infused in the ARC region of laboratory animals. ${ }^{34}$

\section{Defining Treatment Success}

\section{Medical Weight Loss and Individual Expectations}

The percentage excess weight loss [i.e. weight loss/(total weight - normal weight)] after bariatric surgery is usually 50 to $70 \%$, depending on the total intestinal absorption capacity. ${ }^{7}$ GBP is most widely practised, followed by LAGB, and least commonly by BPD with gastric restriction. ${ }^{56}$ Sufficient residual absorption surface after surgery remains critical, because we are still inadequately informed about the health consequences of chronic malabsorption. ${ }^{55}$ Nevertheless, the number of patients happy to undergo primarily malabsorptive procedures is testament to the desperation faced by obese people. In fact, many individuals overvalue thinness in pursuit of cosmetic rather than medical changes and underscore future opportunities through their operation in terms of 'improved control of eating behavior' and a beneficial change of energy homeostasis.

Guidelines for surgical treatment of morbidly obese individuals have been previously formulated, however, without clearly defined treatment goals. ${ }^{58} \mathrm{~A}$ widely accepted medical goal is $10 \%$ weight loss in 6 months, but many patients are more ambitious about the amount of weight they want to lose..$^{57}$ On average, obese women with a BMI of $36.3 \pm 4.3 \mathrm{~kg} / \mathrm{m}^{2}$ reported that their goal was to lose $32 \%$ of their initial weight. These women also reported that their "dream" was to lose $38 \%$, they would be "happy" with $31 \%$, they would "accept" $25 \%$, but they would be "disappointed" with $17 \%$ weight loss. Therefore, acceptable weight loss for most subjects is 2 to 3 times more than that achieved after medical therapy. ${ }^{58}$

\section{Realistic Targets after Bariatric Surgery}

In a large Swedish cohort of men and women who were treated either with LAGB, vertical banded gastroplasty (VBG) or GBP, early and 10 years follow-up data were collected. ${ }^{59}$ The absolute mean weight loss was $23 \%$ at 2 years and $16 \%$ at 10 years follow-up. Early weight loss and 10-year results in subgroups were: LAGB $-21 \pm 10 \%$, VBG $-26 \pm 9 \%$, GBP $-38 \pm 7 \%$, and LAGB $-13 \pm 13 \%$, VBG $-17 \pm 11 \%$, and GBP $-25 \pm 11 \%$, respectively. In other words, these data demonstrate that 'acceptable' or $\sim 25 \%$ loss of initial weight can be achieved with bariatric surgery. Moreover, the mean BMI of the Swedish cohort was $41.3 \pm 4.0 \mathrm{~kg} / \mathrm{m}^{2}$, which automatically means that patients must have lost 50 to $70 \%$ of their excess weight (Table 1). Furthermore, excess weight loss after primarily malabsorptive surgery, i.e. with a long biliopancreatic limb combined with a distal gastrectomy ${ }^{60}$ or with a $75 \%$ vertical gastrectomy ${ }^{61-63}$ will result into $\sim 70$ to $90 \%$ loss of excess weight, which is in agreement with some $40 \%$ of the initial weight (in BMIs exceeding $40 \mathrm{~kg} / \mathrm{m}^{2}$, Table 1).

\section{Weight Loss after Effective and Safe Bariatric Surgery}

In contrast to restrictive techniques, primarily malabsorptive surgery usually leads to negligible weight regain, depending on the length of the common channel. ${ }^{64-68}$ The question remains what type of surgery is effective in terms of control and metabolism,

Table 1.50 to $70 \%$ loss of excess weight corresponds to $25 \%$ loss of initial weight for BMls $35-45 \mathrm{~kg} / \mathrm{m}^{2}$, and to $40 \%$ loss of initial weight for BMls $>45 \mathrm{~kg} / \mathrm{m}^{2}$

\begin{tabular}{|c|c|c|c|c|c|}
\hline \multirow[b]{2}{*}{$\begin{array}{l}\text { Weight } \\
\text { (kg) }\end{array}$} & \multirow[b]{2}{*}{$\begin{array}{c}\mathrm{BMI} \\
\left(\mathrm{kg} / \mathrm{m}^{2}\right)\end{array}$} & \multicolumn{3}{|c|}{ Calculated weight loss in a subject of height $1.70 \mathrm{~m}$} & \multirow[b]{2}{*}{$\begin{array}{c}70 \% \text { loss of } \\
\text { excess weight }(\mathrm{kg})\end{array}$} \\
\hline & & $\begin{array}{l}40 \% \text { weight } \\
\text { loss }(\mathrm{kg})\end{array}$ & $\begin{array}{l}25 \% \text { weight } \\
\text { loss }(\mathrm{kg})\end{array}$ & $\begin{array}{l}50 \% \text { loss of } \\
\text { excess weight }(\mathrm{kg})\end{array}$ & \\
\hline 190 & 65 & 115 & 143 & 130 & 113 \\
\hline 160 & 55 & 95 & 120 & 115 & 98 \\
\hline 130 & 45 & 78 & 98 & 100 & 88 \\
\hline 115 & 40 & 70 & 85 & 93 & 83 \\
\hline 100 & 35 & 60 & 75 & 85 & 80 \\
\hline
\end{tabular}


cosmetically acceptable, and without unforeseen health risks. There are no scientific answers unfortunately, because long-term safety data have not been published. Observational studies about safety issues after gastrectomy are mainly about the issue of longterm bone health. Early gastric cancer is frequently observed in the Japanese population and treated with total gastrectomy at an early stage. It appears that the risk to sustain osteoporotic fractures is positively associated with post gastric resection.

In order to be cautious, we advocate 'safe surgery', meaning effective techniques resulting in 'acceptable' weight loss, i.e. $25 \%$ of initial weight loss down to a BMI between 30 and $40 \mathrm{~kg} / \mathrm{m}^{2}$, depending on the baseline BMI. ${ }^{68}$ In this concept, individuals with an initial BMI of, for example, 55 $\mathrm{kg} / \mathrm{m}^{2}$ should reduce to $35 \mathrm{~kg} / \mathrm{m}^{2}$, while in the case of an initial BMI of, for example, $43 \mathrm{~kg} / \mathrm{m}^{2}$ a reduction to $30 \mathrm{~kg} / \mathrm{m}^{2}$ would do very well. These amounts of weight loss are in agreement with 50 to $70 \%$ loss of excess weight (Table 2). Until today, it is unknown whether BMIs $\leq 30 \mathrm{~kg} / \mathrm{m}^{2}$, which are in agreement with $>90 \%$ loss of excess weight, are safe in the long-term (Table 3). To convince patients, it may be helpful to argue that their surgery is meant to lose weight by improving their eating control and to optimize metabolism. People should undergo surgery aiming to realize an acceptable body weight and, albeit sometimes difficult to convince patients, to avoid unpredictable health risks due to procedures for cosmetic dreams.

In conclusion, the two main ways to become fat, i.e. obesogenic environments wherein people overfeed themselves with excess calories with detrimental metabolic effects, and are sedentary, are effectively treated with a bariatric operation. Yet, no evidence is available about the safest technique for individual patients. Bariatric surgery, particularly the restrictive part, is useful to restore the balance between reward and punishment, thereby improving eating behavior and energy homeostasis. These educational and metabolic aspects prevail above cosmetic arguments, which could lead to a radical operation with unpredictable effects later in life. Based on common sense, we propose to target any operation to a reduction of 30 to $40 \%$ of initial weight or 50 to $70 \%$ of excess weight. Prospective controlled studies concerning long-term efficacy and safety aspects are critical for algorithms for tailor-made bariatric surgery.

Table 2. Calculated weight loss after weight reduction down to $75 \mathrm{~kg}$ (meaning a BMI of $25 \mathrm{~kg} / \mathrm{m}^{2}$ ) expressed as initial or excess weight loss

\begin{tabular}{|c|c|c|c|c|c|}
\hline \multicolumn{6}{|c|}{ Weight loss to a BMI of $25 \mathrm{~kg} / \mathrm{m}^{2}$ in a subject of height $1.70 \mathrm{~m}$} \\
\hline $\begin{array}{l}\text { Weight } \\
\text { (kg) }\end{array}$ & $\begin{array}{c}\text { BMI before } \\
\text { surgery }\left(\mathrm{kg} / \mathrm{m}^{2}\right)\end{array}$ & $\begin{array}{c}\text { Weight } \\
\text { (kg) }\end{array}$ & $\begin{array}{c}\text { BMI after } \\
\text { surgery }\left(\mathrm{kg} / \mathrm{m}^{2}\right)\end{array}$ & $\begin{array}{l}\text { Loss of initial } \\
\text { weight }(\%)\end{array}$ & $\begin{array}{c}\text { Loss of excess } \\
\text { weight (\%) }\end{array}$ \\
\hline 190 & 65 & 75 & 25 & 61 & 96 \\
\hline 160 & 55 & 75 & 25 & 54 & 94 \\
\hline 130 & 45 & 75 & 25 & 43 & 92 \\
\hline 115 & 40 & 75 & 25 & 37 & 89 \\
\hline
\end{tabular}

Table 3. Calculated weight loss after weight reduction to 40 in heaviest, to 35 in middle heavy, and to $30 \mathrm{~kg} / \mathrm{m}^{2}$ in least heavy individuals, expressed as initial or excess weight loss, at height $1.70 \mathrm{~m}$

\begin{tabular}{|c|c|c|c|c|c|}
\hline \multicolumn{6}{|c|}{ Weight loss to a BMI of $30-40 \mathrm{~kg} / \mathrm{m}^{2}$ in a subject of height $1.70 \mathrm{~m}$} \\
\hline $\begin{array}{l}\text { Weight } \\
\text { (kg) }\end{array}$ & $\begin{array}{c}\text { BMI before } \\
\text { surgery }\left(\mathrm{kg} / \mathrm{m}^{2}\right)\end{array}$ & $\begin{array}{l}\text { Weight } \\
\text { (kg) }\end{array}$ & $\begin{array}{c}\text { BMI after } \\
\text { surgery }\left(\mathrm{kg} / \mathrm{m}^{2}\right)\end{array}$ & $\begin{array}{l}\text { Loss of initial } \\
\text { weight }(\%)\end{array}$ & $\begin{array}{c}\text { Loss of excess } \\
\text { weight (\%) }\end{array}$ \\
\hline 190 & 65 & 115 & 40 & 39 & 63 \\
\hline 160 & 55 & 100 & 35 & 38 & 67 \\
\hline 130 & 45 & 88 & 30 & 32 & 70 \\
\hline 115 & 40 & 88 & 30 & 23 & 61 \\
\hline
\end{tabular}




\section{References}

1. World Health Organization. Obesity: preventing and managing the global epidemic. Geneva: WHO, 1997; 894.

2. WHO. World Health Organization technical report series, No 916, March 2003. www.who.int/hpr/nutrition/expertconsultationge.htm.

3. Bray GA. Weight homeostasis. Annu Rev Med 1991; 42: 205-16.

4. Keesey RE, Hirvonen MD. Body weight set-points: determination and adjustment. J Nutr 1997; 127: 1875S-183S.

5. Third report of the National Cholesterol Education Program (NCEP) expert panel on detection, evaluation, and treatment of high blood cholesterol in adults (Adult Treatment Panel III). Final report. Circulation 2002; 106: 3143-421.

6. Suter M, Calmes JM, Paroz A et al. A 10-year experience with laparoscopic gastric banding for morbid obesity: high long-term complication and failure rates. Obes Surg 2006; 16: 829-35.

7. Buchwald H, Avidor Y, Braunwald E et al. Bariatric surgery: a systematic review and meta-analysis. JAMA 2004; 292: 1724-37.

8. Pavlov IP. The centrifugal (efferent) nerves to the gastric glands and of the pancreas. Thompson WH, translator. The Work of the Digestive Glands, 2nd Edn. Philadelphia: Charles Griffin, 1910: 48-59.

9. Knutson U, Olbe L, Ganguli PC. Gastric acid and plasma gastrin responses to sham feeding in duodenal ulcer patients before and after resection of antrum and duodenal bulb. Scand J Gastroenterol 1974; 9: 351-6.

10. Richardson CT, Walsh JH, Cooper KA et al. Studies on the role of cephalic-vagal stimulation in the acid secretory response to eating in normal human subjects. J Clin Invest 1977; 60: 435-41.

11. Feldman M, Richardson CT. Role of thought, sight, smell, and taste of food in the cephalic phase of gastric acid secretion in humans. Gastroenterology 1986; 90: 428-33.

12. Petrovich GD, Holland PC, Gallagher M. Amygdalar and prefrontal pathways to the lateral hypothalamus are activated by a learned cue that stimulates eating. J Neurosci 2005 ; 25: 8295-302.

13. Booth DA. Mood- and nutrient-conditioned appetites. Cultural and physiological bases for eating disorders. Ann N Y Acad Sci 1989; 575: 122-35 and discussion 157-62.

14. De Castro JM. Socio-cultural determinants of meal size and frequency. Br J Nutr 1997; Suppl 1: S39-S54.

15. Hoek J, Gendall P. Advertising and obesity: a behavioral perspective. J Health Commun 2006; 11: 409-23.

16. Joosen AM, Westerterp KR. Energy expenditure during overfeeding. Nutr Metab (Lond) 2006; 12: 25 http://www.nutritionandmetabolism.com/content/3/1/25

17. Dallman MF, Akana SF, Strack AM et al. Chronic stressinduced effects of corticosterone on brain: direct and indirect. Ann NY Acad Sci 2004; 1018: 141-50.

18. Merali Z, McIntosh J, Anisman H. Anticipatory cues differentially provoke in vivo peptidergic and monoaminergic release at the medial prefrontal cortex. Neuro- psychopharmacology 2004; 29: 1409-18.

19. Pecoraro N, Gomez F, Dallman MF. Glucocorticoids dosedependently remodel energy stores and amplify incentive relativity effects. Neuropsychopharmacology 2005; 30: 815-25.

20. Erlanson-Albertsson C. How palatable food disrupts appetite regulation. Basic Clin Pharmacol Toxicol 2005; 97: 61-73.

21. Berridge KC. Food reward: brain substrates of wanting and liking. Neurosci Biobehav Rev 1996; 20: 1-25.

22. Epstein LH, Truesdale R, Wojcik A et al. Effects of deprivation on hedonistics and reinforcing value of food. Physiol Behav 2003; 78: 221-7.

23. Kennedy GC. The regulation of food intake. Discussion. Adv Psychosom Med 1972; 7: 91-9.

24. Schwartz MW, Porte D Jr. Diabetes, obesity, and the brain. Science 2005; 307: 375-9.

25. Niswender KD, Baskin DG, Schwartz MW. Insulin and its evolving partnership with leptin in the hypothalamic control of energy homeostasis. Trends Endocrinol Metab 2004; 15: 362-9.

26. Plum L, Schubert M, Bruning JC. The role of insulin receptor signaling in the brain. Trends Endocrinol Metab 2005; 16: 59-65.

27. Gerozissis K. Brain insulin and feeding: a bi-directional communication. Eur J Pharmacol 2004; 490: 59-70.

28. Obici S, Zhang BB, Karkanias G et al. Hypothalamic insulin signaling is required for inhibition of glucose production. Nat Med 2002; 8: 1376-82.

29. Pocai A, Lam TK, Gutierrez-Juarez R et al. Hypothalamic $\mathrm{K}$ (ATP) channels control hepatic glucose production. Nature 2005; 434: 1026-31.

30. Bruning JC, Gautam D, Burks DJ et al. Role of brain insulin receptor in control of body weight and reproduction. Science 2000; 289: 2122-5.

31. Burks DJ, de Mora JF, Schubert M et al. IRS-2 pathways integrate female reproduction and energy homeostasis. Nature 2000; 407: 377-82.

32. Halaas JL, Boozer C, Blair-West J et al. Physiological response to long-term peripheral and central leptin infusion in lean and obese mice. Proc Natl Acad Sci USA 1997; 94: 8878-83.

33. Schwartz MW, Woods SC, Porte D Jr et al. Central nervous system control of food intake. Nature 2000; 404: 661-71.

34. Prodi E, Obici S. Minireview: the brain as a molecular target for diabetic therapy. Endocrinology 2006; 147: 2664-9.

35. Baskin DG, Schwartz MW, Seeley RJ et al. Leptin receptor long-form splice-variant protein expression in neuron cell bodies of the brain and co-localization with neuropeptide Y mRNA in the arcuate nucleus. J Histochem Cytochem 1999; 47: 353-62.

36. Niswender KD, Morrison CD, Clegg DJ et al. Insulin activation of phosphatidylinositol 3-kinase in the hypothalamic arcuate nucleus: a key mediator of insulin-induced anorexia. Diabetes 2003; 52: 227-31.

37. Sun XJ, Rothenberg P, Kahn CR et al. Structure of the insulin receptor substrate IRS-1 defines a unique signal transduction protein. Nature 1991; 352: 73-7. 
38. Sun XJ, Wang LM, Zhang Y et al. Role of IRS-2 in insulin and cytokine signaling. Nature 1995; 377: 173-7.

39. Folli F, Saad MJ, Backer JM et al. Insulin stimulation of phosphatidylinositol 3-kinase activity and association with insulin receptor substrate 1 in liver and muscle of the intact rat. J Biol Chem 1992; 267: 22171-7.

40. Carvalheira JB, Torsoni MA, Ueno M et al. Cross-talk between the insulin and leptin signaling systems in rat hypothalamus. Obes Res 2005; 13: 48-57.

41. Morton GJ, Gelling RW, Niswender KD et al. Leptin regulates insulin sensitivity via phosphatidylinositol-3-OH kinase signaling in mediobasal hypothalamic neurons. Cell Metab 2005; 2: 411-20.

42. Bjorbaek C, Uotani S, da Silva B et al. Divergent signaling capacities of the long and short isoforms of the leptin receptor. J Biol Chem 1997; 272: 32686-95.

43. Bates SH, Meyers MG. The role of leptin-->STAT3 signaling in neuroendocrine function: an integrative perspective. $\mathrm{J}$ Mol Med 2004; 82: 12-20.

44. Niswender KD, Morton GJ, Steams WH et al. Intracellular signaling. Key enzyme in leptin-induced anorexia. Nature 2001; 413: 794-5.

45. Schwartz MW, Baskin DG, Bukowski TR et al. Specificity of leptin action on elevated blood glucose levels and hypothalamic neuropeptide $\mathrm{Y}$ gene expression in ob/ob mice. Diabetes 1996; 45: 531-35.

46. Schwartz MW, Seeley RJ, Woods SC et al. Leptin increases hypothalamic pro-opiomelanocortin mRNA expression in the rostral arcuate nucleus. Diabetes 1997; 46: 2119-23.

47. Thornton JE, Cheung CC, Clifton DK et al. Regulation of hypothalamic proopiomelanocortin mRNA by leptin in ob/ob mice. Endocrinology 1997; 138: 5063-66.

48. Mercer JG, Moar KM, Rayner DV et al. Regulation of leptin receptor and NPY gene expression in hypothalamus of leptin-treated obese (ob/ob) and cold-exposed lean mice. FEBS Lett 1997; 402: 185-8.

49. Mizuno TM, Kleopoulos SP, Bergen HT et al. Hypothalamic pro-opiomelanocortin mRNA is reduced by fasting in ob/ob and $\mathrm{db} / \mathrm{db}$ mice, but is stimulated by leptin. Diabetes 1998; 47: 294-7.

50. Cornier MA, Bergman BC, Bessesen DH. The effects of short-term overfeeding on insulin action in lean and reduced-obese individuals. Metabolism 2006; 55: 1207-14.

51. Tzatsos A, Kandror KV. Nutrients suppress phosphatidylinositol 3-kinase/Akt signaling via raptor-dependent mTORmediated insulin receptor substrate 1 phosphorylation. Mol Cell Biol 2006; 26: 63-76.
52. Pocai A, Lam TK, Obici S et al. Restoration of hypothalamic lipid sensing normalizes energy and glucose homeostasis in overfed rats. J Clin Invest 2006; 116: 1081-91.

53. Kasuga M. Insulin resistance and pancreatic beta cell failure. J Clin Invest 2006; 116: 1756-60.

54. Buchwald H, Williams SE. Bariatric surgery worldwide 2003 Obes Surg 2004; 14: 1157-64.

55. Parfitt AM, Podenphant J, Villanueva AR et al. Metabolic bone disease with and without osteomalacia after intestinal bypass surgery: a bone histomorphometric study. Bone 1985; 6: 211-20.

56. The Practical Guide: Identification, Evaluation, and Treatment of Overweight and Obesity in Adults. October 2000, NIH Pub No 00-4084.

57. Rabner JG, Greenstein RJ. Obesity surgery: expectations and reality. Int J Obes Relat Metab Disord 1991; 15: 841-55.

58. Foster GD, Wadden TA, Vogt RA et al. What is a reasonable weight loss? Patients' expectations and evaluations of obesity treatment outcomes. J Consult Clin Psychol 1997; 65: 79-85.

59. Sjostrom L, Lindroos AK, Peltonen $M$ et al. Lifestyle, diabetes, and cardiovascular risk factors 10 years after bariatric surgery. N Engl J Med 2004; 351: 2683-93.

60. Scopinaro N, Gianetta E, Civalleri D et al. Bilio-pancreatic bypass for obesity: II. Initial experience in man. Br J Surg 1979; 66: 618-20.

61. Hess DS, Hess DW. Biliopancreatic diversion with a duodenal switch. Obes Surg 1998; 8: 267-82.

62. Lagace M, Marceau P, Marceau S, et al. Biliopancreatic diversion with a new type of gastrectomy: some previous conclusions revisited. Obes Surg 1995; 5: 411-18.

63. Anthone GJ, Lord RV, DeMeester TR et al. The duodenal switch operation for the treatment of morbid obesity. Ann Surg 2003; 238: 618-27.

64. Biron S, Hould FS, Lebel S et al. Twenty years of biliopancreatic diversion: what is the goal of the surgery? Obes Surg 2004; 14: 160-4.

65. McConnell DB, O'rourke RW, Deveney CW. Common channel length predicts outcomes of biliopancreatic diversion alone and with the duodenal switch surgery. Am J Surg 2005; 189: 536-40.

66. Dalle Grave R, Calugi S, Magri F et al. Weight loss expectations in obese patients seeking treatment at medical centers. Obes Res 2004; 12: 2005-12.

(Received November 20, 2006; accepted January 11, 2007) 